\title{
MORALNA OCENA STOSOWANIA NIEKTÓRYCH SZCZEPIONEK PRZECIW COVID-19 W ŚWIETLE PERSONALIZMU CHRZEŚCIJAŃSKIEGO
}

DOI: http://dx.doi.org/10.12775/TiCz.2021.001

Streszczenie. Celem artykułu jest ocena moralna stosowania szczepionek przeciwko COVID-19, do których produkcji wykorzystano linie komórkowe zapoczątkowane komórkami pobranymi od uśmierconych ludzkich płodów. Kryterium tej oceny jest norma personalistyczna, zgodnie z którą czyn jest moralnie dobry wtedy, gdy przyczynia się do afirmacji osoby dla niej samej. Na początku pracy zostało krótko wyjaśnione, czym są tzw. linie komórek zarodkowych oraz na czym polega technologia produkcji szczepionek opartych na takich liniach. Następnie wskazano, które z obecnie dostępnych szczepionek przeciw COVID-19 są produkowane dzięki wykorzystaniu linii zarodkowych. Na koniec dokonano analizy zarzutów wysuwanych przeciwko wspomnianej technologii.

Słowa kluczowe: linie komórkowe; szczepionki; SARS-CoV-2; COVID-19; pandemia; personalizm.

Abstract. Moral Evaluation of Using Certain Types of COVID-19 Vaccines in the Light of Christian Personalism. This article offers a moral evaluation of the use of COVID-19 vaccines obtained from human cell lines that originate from aborted human foetuses. The criterion of this evaluation is the personalistic norm which states that an act is morally good if it contributes to the affirmation of a person for that person alone. The paper begins with a brief explanation of what foetal cell lines are and what technology 
is used in the production of vaccines that use such cell lines. Then, it indicates which of the currently available COVID-19 vaccines are produced using foetal cell lines. Finally, it examines the objections that are being raised against the technology in question.

Keywords: cell lines; vaccines; SARS-CoV-2; COVID-19; pandemic; personalism.

\section{WSTĘP}

W ostatnich miesiącach roku 2019 w chińskiej miejscowości Wuhan pojawił się nowy rodzaj koronawirusa, którego nazwano SARS-CoV-2. Wkrótce okazało się, że wirus ten może stanowić śmiertelne zagrożenie, wywołując chorobę COVID-19. Jednym ze sposobów opanowania choroby było wynalezienie szczepionki. Powstało kilka rodzajów szczepionek przeciw COVID-19, różniących się właściwościami i sposobem produkcji. Celem niniejszej pracy jest próba moralnej oceny stosowania szczepionek opartych na technologii wykorzystującej ludzkie linie zarodkowe. Każdą ocenę moralną wydaje się w ramach jakiegoś paradygmatu. W tym artykule przyjmiemy paradygmat chrześcijański, a konkretnie szeroko pojęty personalizm, rozumiany jako pogląd, zgodnie z którym czyn jest moralnie dobry tylko wtedy, gdy przyczynia się do afirmacji osoby dla niej samej ${ }^{1}$.

Na początku krótko wyjaśnimy, czym są linie komórkowe i jaką rolę pełnią ludzkie linie zarodkowe w procesie wytwarzania szczepionek. Następnie przedstawimy cztery główne zarzuty etyczne wysuwane przeciwko zastosowaniu ludzkich linii zarodkowych w biotechnologii i poddamy je krytyce. W konkluzji znajdzie się stwierdzenie, że stosowanie szczepionek przeciw COVID-19, do których produkcji wykorzystano wspomniane linie, nie powinno budzić wątpliwości moralnych. Celem tej pracy nie jest natomiast ani ocena skuteczności lub szkodliwości szczepionek, ani analiza problemu przymusu prawnego ich przyjmowania, ani agitacja pro- lub antyszczepionkowa.

${ }^{1}$ Zob. T. Styczeń, Etyka czy etyki?, „Roczniki Filozoficzne” 29/2 (1981), s. 90-111; F. W. Bednarski, „Osobie jako osobie należna jest od osoby jako osoby afirmacja”, „Roczniki Filozoficzne” 29/2 (1981), s. 112-117; A. Szostek, Wokół afirmacji osoby. Próby uściśleń inspirowane dyskusja nad koncepcja etyki ks. Tadeusza Stycznia, „Roczniki Filozoficzne” 32/2 (1984), s. 149-166. 


\section{ROLA LINII ZARODKOWYCH W PROCESIE WYTWARZANIA SZCZEPIONEK PRZECIW COVID-19}

Kultury komórkowe są to hodowle komórek (tkanek lub narządów) wyodrębnionych z organizmów wielokomórkowych i utrzymywanych przy życiu in vitro, czyli poza organizmem żywym, w ściśle określonych warunkach, dłużej niż 24 godziny. Hodowle komórkowe stosuje się np. do badania biologii komórek, badań toksykologicznych, dermatologicznych, medycznych (np. badania leków), produkcji przeciwciał monoklonalnych, terapii genowej, hodowania wirusów, produkcji szczepionek i innych ${ }^{2}$. Technologię hodowli komórek zapoczątkował Ross Granville Harrison, który w roku 1907 umieścił wycinki tkanki nerwowej zarodka żaby w kropli skrzepłej limfy i wykazał doświadczalnie, że funkcja fizjologiczna komórki może być kontynuowana in vitro. Z kolei amerykański chirurg Alexis Carrel podczas hodowli komórkowej zastosował zasady antyseptyki, dzięki czemu hodowla (w sterylnym boksie, wysterylizowanym szkle i jałowych pożywkach) mogła być prowadzona przez długi czas bez zakażenia ${ }^{3}$.

Pod koniec roku 2020 świat obiegła wiadomość, że producenci niektórych szczepionek przeciw COVID-19 wykorzystują linie komórkowe pochodzące od ludzkich komórek zarodkowych, pobranych w trakcie wykonywania zabiegów aborcji. Ta informacja spowodowała, że odżyły istniejące od wielu lat kontrowersje dotyczące godziwości i konieczności stosowania takiej technologii. Szczególne zaniepokojenie zrodziło się w kręgach chrześcijańskich. Trzeba jasno powiedzieć, że od strony technicznej użyteczność linii komórkowych pochodzących od płodów ludzkich jest w wakcynologii oceniana bardzo wysoko. Decydują o tym głównie względy bezpieczeństwa. Narodowy Instytut Zdrowia Publicznego podkreśla, że wykorzystywanie przy produkcji szczepionek linii komórkowych odzwierzęcych mogłoby się wiązać się z możliwością wprowadzenia do szczepionki obcych wirusów ${ }^{4}$ albo wystąpienia u pacjentów reakcji

2 Zob. P. Stasiak, M. Sznitowska, Zastosowanie hodowli komórkowych w badaniach biofarmaceutycznych, „Farmacja Polska” 66/3 (2010), s. 228-229.

3 S. Stokłosowa (red.), Hodowla komórek i tkanek, PWN, Warszawa 2006, s. 2.

4 Taka sytuacja pojawiła się choćby w latach 60 . XX wieku, kiedy wykryto obecność wirusa SW40 w żywej szczepionce przeciw poliomyelitis. 
alergicznych na białka zwierzęce. Z kolei stosowanie komórek ludzi dorosłych stworzyłoby ryzyko pozyskania linii, która uległa mutacji, czyli przekształciła się w linię nowotworową, co mogłoby skutkować wprowadzeniem do szczepionki genu nowotworowego ${ }^{5}$.

Zanim powiemy, jaką rolę pełnią ludzkie linie zarodkowe w procesie wytwarzania szczepionki, przybliżmy, na czym w ogóle polega mechanizm działania tych szczepionek. Zdecydowana większość szczepionek przeciw COVID-19 to tzw. Szczepionki rekombinowane, otrzymane na drodze inżynierii genetycznej. Do szczepionek rekombinowanych zaliczamy szczepionki wektorowe i szczepionki mRNA. Szczepionki wektorowe zawierają pewne aktywne wirusy zmodyfikowane w taki sposób, by zostało zminimalizowane ryzyko zakażenia pacjenta. Są to wirusy inne niż ten, na który ma zostać wzbudzona odporność, i stanowią one tylko „środek transportu” dla jego kodu genetycznego. Dopiero wprowadzenie szczepionki do organizmu pacjenta wywołuje produkcję przez organizm białka właściwego wirusa i odpowiedź immunologiczną. Do szczepionek wektorowych przeciw COVID-19 należą np. preparaty firm AstraZeneca i Johnson\&Johnson. Szczepionki mRNA, najbardziej nowoczesne, wykorzystują kwas rybonukleinowy (RNA) jako matrycę do produkcji białek wirusowych, które mają wywołać produkcję przeciwciał. W przypadku szczepionek mRNA do organizmu jest podawana tylko informacja genetyczna o tym, jak dane białko powinno być wytworzone, natomiast produkcja tego białka odbywa się dopiero w komórkach organizmu pacjenta. To znaczy, że w przypadku szczepionek mRNA nie podaje się pacjentowi gotowego antygenu, lecz „przepis”, instrukcję jego przygotowania w postaci mRNA kodującego informację o białku pełniącym funkcję antygenu. Do szczepionek mRNA należą preparaty firm Pfizer/BioNTech i Moderna ${ }^{6}$.

${ }^{5}$ Zob. Jak się bada bezpieczeństwo szczepionek?, https://szczepienia.pzh.gov.pl/ wszystko-o-szczepieniach/jak-sie-bada-bezpieczenstwo-szczepionek/?print-version (dostęp: 05.02.2021).

${ }^{6}$ Zob. L. Borkowski, M. Drąg, A.M. Fal i in. Szczepienia przeciw COVID-19. Innowacyjne technologie i efektywność, Warszawa 2020, s. 10, https://www.gov.pl/web/szczepimysie/startuje-inicjatywa-nauka-przeciw-pandemii-na-rzecz-dostarczenia-rzetelnejinformacji-dotyczacej-szczepien-przeciw-covid-19-bezpieczenstwa-i-stosowanych-technologii (dostęp: 05.02.2021). 
Nie wszyscy producenci szczepionek przeciw COVID-19 wykorzystują na którymś z etapów produkcji linie komórkowe pochodzące od ludzkich płodów. Wiadomo, że na dzień 22 września 2020 r. spośród kilkudziesięciu opracowywanych szczepionek, w przypadku co najmniej pięciu $\mathrm{z}$ nich ${ }^{7}$ skorzystano $\mathrm{z}$ jednej $\mathrm{z}$ dwóch ludzkich linii zarodkowych - były to linie HEK-293 i PER.C6. Linie te posłużyły do produkcji szczepionek wektorowych i zostały wykorzystane wyłącznie w celu namnażania adenowirusa, czyli wirusa osłabionego, niezdolnego do replikacji i zakażenia organizmu człowieka. Przykładowo w przypadku szczepionki firmy AstraZeneca w celu wywołania odpowiedzi autoimmunologicznej wykorzystano nieaktywną cząstkę zmodyfikowanego adenowirusa szympansa $^{8} \mathrm{z}$ sekwencją kodującą glikoproteinę $\mathrm{S}$ wirusa SARS-CoV-2. Cząstka ta przenosi białko kolca SARS-CoV-2, a organizm rozpoznaje to białko jako obce, produkuje przeciwciała i aktywuje limfocyty. Adenowirus jest wytwarzany w genetycznie zmodyfikowanych ludzkich embrionalnych komórkach nerki - linia HEK-293 - oraz za pomocą technologii rekombinacji $\mathrm{DNA}^{9}$. Innymi słowy, rolą linii ludzkich komórek zarodkowych

7 Są to preparaty następujących wytwórców: CanSino Biologics, Inc., Beijing Institute of Biotechnology (linia HEK-293), Uniwersytet w Oksfordzie, AstraZeneca (linia HEK-293), Janssen Pharmaceutical Companies (linia PER.C6), Uniwersytet w Pitsburgu (linia HEK-293), ImmunityBio, NantKwest (linia HEK-293). Natomiast szczepionka firm Pfizer/BioNTech korzystała z linii komórkowej tylko na etapie początkowego testowania jej wpływu na ludzkie komórki i nie wykorzystuje ich w sensie ścisłym do produkcji szczepionki. Zob. E. Augustynowicz, Linie komórkowe HEK-293 i PER.C6, https:// www.mp.pl/szczepienia/specjalne/250300,linie-komorkowe-hek-293-i-perc6 (dostęp: 05.02.2021); Stanowisko Zespołu Ekspertów ds. Bioetycznych Konferencji Episkopatu Polski dotyczace szczepionek, 12.

${ }^{8}$ Wykorzystano adenowirusa pochodzenia szympansiego, a nie ludzkiego, z tego powodu, że ludzkie adenowirusy są bardzo powszechne w populacji i moglibyśmy mieć do czynienia z naturalną odpornością na nie, co skutkowałoby obniżeniem skuteczności szczepionki. Zastosowanie adenowirusa szympansiego pozwala uniknąć możliwej odpowiedzi odpornościowej przeciwko samemu wektorowi, zob. M.D.J. Dicks, A.J. Spencer, N. Edward i in. A novel chimpanzee adenovirus vector with low human seroprevalence: improved systems for vector derivation and comparative immunogenicity, „PLoS One”, 7 (2012), https://journals.plos.org/plosone/article?id=10.1371/journal.pone.0040385 (dostęp: 06.02.2021).

9 Zob. Charakterystyka produktu leczniczego COVID-19 Vaccine AstraZeneca zawiesina do wstrzykiwań. Szczepionka przeciw COVID-19 (ChAdOx1-S [rekombinowa- 
w procesie produkcji szczepionki AstraZeneca jest w tym wypadku produkcja dużej ilości wektorów wirusowych, czyli nośników dla genu kodującego wybrane białko wirusa SARS-CoV-2.

Warto dodać, że współczesne linie komórkowe zawierają komórki będące klonami, „potomkami” komórek oryginalnych, pobranych z płodu, i zostały wyhodowane sztucznie. Komórki i tkanki płodowe już od dawna nie istnieją, a więc nie mogą stanowić składu żadnej współczesnej szczepionki. W preparacie szczepionkowym nie mogą znajdować się również komórki należące do linii zarodkowej, gdyż adenowirusy, mnożąc się w linii komórkowej, doprowadzają do zniszczenia komórek należących do linii, a po namnożeniu preparat jest kilkukrotnie oczyszczany z pozostałości komórkowych i materiału z hodowli.

\section{ZARYS PERSONALISTYCZNEJ KONCEPCJI CZłOWIEKA}

Chrześcijańska wizja człowieka opiera się na założeniach personalizmu, który przypisuje godność osobową bytowi ludzkiemu od momentu poczęcia aż do śmierci. Godność osobowa jest zatem wrodzona, niezbywalna i stanowi fundament relacji międzyludzkich. Byt ludzki jest tu ujmowany całościowo, ponieważ posiada jedną zasadę życia i rozwoju, którą w języku filozoficznym od najdawniejszych czasów zwykło się nazywać duszą. W tej koncepcji drugi człowiek nie może być nigdy traktowany tylko jako środek do osiągania pewnych celów, ale powinien być zawsze również celem samym w sobie. Nota bene nurt zwany personalizmem zrodził się właśnie jako protest przeciwko „urzeczowieniu” człowieka, zarówno na płaszczyźnie teoretycznej, jak i w sferze społeczno-politycznej, gdzie próbowano jednostkę podporządkować społeczeństwu ${ }^{10}$. Istnieje wiele odmian personalizmu, natomiast za twórcę tzw. personalizmu chrześcijańskiego uważa się Jacques’a Maritaina, który w swojej teorii wyróżnił dwa komplementarne składniki bytu ludzkiego: osobę i jednostkę. Osoba to owa Boecjańska rationalis naturae individua substantia, o której decyduje niezależny od ciała duch,

na]), https://ec.europa.eu/health/documents/community-register/2021/20210129150842/ anx_150842_pl.pdf (dostęp: 06.02.2021).

${ }_{10}$ Zob. I. Dec, Personalizm, w: Powszechna Encyklopedia Filozofii, t. 8, PTTA, Lublin 2007, s. 122-123. 
natomiast jednostka (indywiduum) to element materialny bytu ludzkiego, fragment wszechświata ${ }^{11}$. Na osobowy charakter człowieka wskazują przede wszystkim jego autonomiczne decyzje i tymi aktami „samowładzy” nikomu, oprócz niego samego, nie wolno zarządzać. Karol Wojtyła podsumowuje to stwierdzeniem, że każda osoba należy do siebie samej, a zatem jest posiadana wyłącznie przez samą siebie ${ }^{12}$. Naturalną konsekwencją takiego ujęcia osoby jest to, że nikomu z zewnątrz nie wolno decydować o jej życiu lub śmierci, nawet na etapie płodowym, ani jej wykorzystywać do realizacji celów, które nie służą jej samej.

\section{PROBLEMY ETYCZNE ZWIAZZANE Z WYKORZYSTYYWANIEM LUDZKICH LINII ZARODKOWYCH}

Rozpatrzymy cztery główne zarzuty, które z punktu widzenia personalisty można wysunąć przeciwko technologiom wykorzystującym ludzkie linie zarodkowe. Zarzuty te można streścić w następujących stwierdzeniach:

- w celu tworzenia linii zarodkowych zostało poświęcone życie ludzkie,

- korzystając z ludzkich linii zarodkowych bierze się współudział w aborcji,

- korzystanie z ludzkich linii zarodkowych jest tzw. przywłaszczeniem zła i prowadzi do skandalu lub promocji kolejnego zła,

- niektóre szczepionki przeciw COVID-19 zawierają elementy uśmierconych płodów ludzkich.

\subsection{PROBLEM CELOWOŚCI HISTORYCZNYCH ABORCJI}

Z personalistycznego punktu widzenia moralnie nieakceptowalne jest dokonanie terminacji ciąży w celu pobrania do dalszych badań komórek lub tkanek uśmierconego płodu, nawet gdyby to miało uratować w przyszłości wiele istnień ludzkich, ponieważ nie wolno poświęcić życia

${ }_{11}$ Zob. J. Maritain, La personne et le bien commun, Paris 1947.

12 Zob. K. Wojtyła, Osoba i czyn, Kraków 1969, s. 110. 
jednej osoby (a tym jest zabicie zarodka ludzkiego) dla ratowania innych osób $^{13}$. Innymi słowy, słuszny cel nigdy nie usprawiedliwia niegodziwego środka. W odniesieniu do linii zarodkowych, zapoczątkowanych komórkami pozyskanymi podczas aborcji, trzeba zadać zasadnicze pytanie: czy wspomniane aborcje rzeczywiście zostały wykonane „w celu” pobrania materiału biologicznego do dalszych badań i eksperymentów? Dzisiejszy stan wiedzy wskazuje na to, że tak nie było. Nie zmienia to oczywiście faktu, że samych zabiegów aborcji na gruncie personalizmu nie da się usprawiedliwić. Natomiast brak wyraźnej celowości aborcji w kierunku biomedycznym jest istotny przy ocenie moralnej działania polegającego na pobraniu komórek zarodkowych przez ówczesnych biotechnologów.

Linia HEK-293 powstała w roku 1973 z embrionalnych komórek nerki w laboratorium Aleksa van der Eba na Uniwersytecie w Leiden w Holandii. Pozyskano ją z ludzkiego płodu poddanego aborcji w roku 1972. Natomiast linię PER.C6 wyprowadzono z tkanki siatkówki osiemnastotygodniowego płodu, uzyskanej w wyniku zabiegu sztucznego poronienia przeprowadzonego w roku 1985: matka chciała się pozbyć płodu, ojciec dziecka był nieznany. Podobnie jak linię HEK-293, linię PER.C6 wytworzono w laboratorium Alexa van der Eba. Obydwa uśmiercone płody były zdrowe ${ }^{14}$. Istnieje wiele starych linii, innych niż HEK-293 i PER.C6, zapoczątkowanych komórkami pobranymi z uśmierconych ludzkich płodów. Również w ich przypadku pobranie komórek nie było jakąkolwiek motywacją przerwania ciąży ${ }^{15}$. Na przykład materiałem służącym do zainicjowania linii WI-38 był fibroblast płucny płodu płci żeńskiej, który został uśmiercony, ponieważ rodzice uznali, że mają już zbyt wiele dzieci. Co prawda, ze względu na swoje właściwości, ten konkretny płód został

13 Zob. M. Wadman, Medical research: cell division, „Nature” 498 (2013), s. $422-426$.

${ }^{14}$ R. Leiva, A Brief History of Human Diploid Cell Strains, „The National Catholic Bioethics Quarterly" 6 (2006), s. 447.

${ }^{15}$ Co więcej, jak twierdzi dr E. Norrby, w latach 60. XX wieku, kiedy pobierano materiał biologiczny od abortowanych płodów i wysyłano go do instytutu Wistar, nie istniało jeszcze coś takiego, jak świadoma zgoda. Jest więc bardzo prawdopodobne, że nigdy się nie dowiemy, czy matki zdawały sobie w ogóle sprawę z tego, że ich płody zostały wykorzystane do zainicjowania linii komórkowych, zob. R. Leiva, A Brief History of Human Diploid Cell Strains, „The National Catholic Bioethics Quarterly” 6 (2006), s. 450. 
wyselekcjonowany, „zaplanowany” do pobrania komórek, jednak decyzja o aborcji była pierwotna w stosunku do decyzji o pobraniu materiału biologicznego ${ }^{16}$. Meredith Wadman $\mathrm{w}$ jednej ze swoich prac pisze o tym wydarzeniu tak:

Płód płci żeńskiej o długości $20 \mathrm{~cm}$, owinięty w sterylną zieloną tkaninę, został dostarczony do Instytutu Karolinska w północno-zachodnim Sztokholmie. Tam wypreparowano płuca, umieszczono je w lodzie i wysłano na lotnisko, gdzie zostały załadowane na lot transatlantycki. Kilka dni później Leonard Hayflick, ambitny młody mikrobiolog z Instytutu Anatomii i Biologii Wistar w Filadelfii, w Pensylwanii, rozpakował przesyłkę. Za pomocą skalpela Hayflick rozdrobnił płuca - każde mniej więcej wielkości opuszki palca dorosłego człowieka - a następnie umieścił je w kolbie z mieszanką enzymów, które rozbiły je na poszczególne komórki. Następnie przeniósł materiał do kilku płaskich szklanych butelek, do których dodał pożywkę. Położył butelki na bokach w pomieszczeniu inkubacyjnym o temperaturze $37^{\circ} \mathrm{C}$. Komórki zaczęły się dzielić ${ }^{17}$.

W takim kontekście proces pobrania komórek można by próbować ocenić analogicznie do pobrania narządów do transplantacji ${ }^{18}$. Włodzimierz Gut twierdzi wprost, że samo pobranie komórek nie miało nic wspólnego $\mathrm{z}$ wykonaniem aborcji, a uśmiercony płód i tak by został

16 Zob. R. Lundstrom, S. Plotkin i in. Gamma Globulin Prophylaxis; Inactivated Rubella Virus; Production and Biologics Control of Live Attenuated Rubella Virus Vaccines. Discussion on Session V, „American Journal of Diseases of Children 118 (1969), s. 378.

17 M. Wadman, Medical research: cell division, „Nature” 498 (2013), s. 422.

${ }^{18}$ Niektórzy autorzy podkreślają, że zabieg aborcji, w czasie którego pobiera się tkanki do celów biomedycznych, nigdy nie jest „przypadkowy”. Tomasz Orłowski podaje: „Jakość płodu musiała zostać wcześniej zdiagnozowana, [...] aborcja odpowiednio i starannie przygotowana, pobranie tkanek przeprowadzone natychmiast po zabiegu [...]. Warto zaznaczyć, że pobrania komórek dokonuje się bezpośrednio po aborcji, kiedy jeszcze wszystkie ich funkcje życiowe są zachowane” (zob. T. Orłowski, Szczepionki produkowane na liniach komórkowych pochodzenia płodowego - problemy etyczne, „Studia Redemptorystowskie" 9-1 (2011), s. 82-83). Z tego Orłowski wnioskuje, że w praktyce nigdy nie mamy do czynienia ze „skorzystaniem z okazji”, ale z nakłanianiem do aborcji starannie dobranych pacjentek. Wydaje się, że Orłowski dokonuje tu nadinterpretacji i po prostu dokonuje oceny moralnej aborcji (bezpośredniej lub pośredniej), a nie pobrania tkanek abortowanego płodu. 
poddany standardowej utylizacji przez spalenie ${ }^{19}$. Oczywiście między zespołem medyków dokonujących aborcji a zespołem pobierającym komórki zachodziła ścisła techniczna współpraca i trudno oszacować wkład każdego z zespołów w procedurę aborcyjną, jednak nie powinno się raczej twierdzić, że płód został uśmiercony „dla” nauki. W związku z tym należałoby zachować ostrożność w negatywnej ocenie moralnej uczestników zespołu preparującego linię komórkową.

Można by zilustrować to jeszcze inaczej. Wyobraźmy sobie sytuację, w której pewna osoba A zostaje zamordowana. Jednakże serce osoby A nadaje się jeszcze do przeszczepu. Wyobraźmy sobie następnie, że znajduje się osoba B, która mogłaby być biorcą serca osoby A. W obliczu nieuniknionej śmierci osoby A (właściwie śmierć pnia mózgu osoby A została już stwierdzona), nie ma moralnych przeszkód w pozyskaniu organu osoby A (aby uniknąć dodatkowych komplikacji, załóżmy, że osoba A wyraziła przed śmiercią zgodę na pobranie od niej narządów). To jednak wcale nie jest równoznaczne $\mathrm{z}$ aprobatą aktu zabójstwa osoby A. Czy sam fakt zabójstwa osoby A, a nie jej śmierć naturalna lub w wypadku, dyskwalifikuje moralną akceptację przeszczepu? Wydaje się, że nie. W tej sytuacji winą obarczony jest zabójca osoby A, który działał ze znanych sobie pobudek, ale nie osoba wykonująca przeszczep, czy sam biorca (oczywiście, sytuacja moralna zmieniłaby się istotnie, gdyby osoba A została zamordowana w celu pobrania od niej serca dla osoby B i gdyby osoba B miała tego świadomość). Analogicznie, można by próbować uznać za moralnie dopuszczalne współczesne wykorzystywanie linii zarodkowych, nawet przy jednoczesnym braku akceptacji dla aborcji dokonanych przed laty. Podobnie, jak osoba B z przedstawionego eksperymentu myślowego, tak ludzie współcześni nie mieli żadnego wpływu na zło popełnione $\mathrm{w}$ przeszłości, a sama akceptacja wykorzystywania współczesnych linii zarodkowych nie jest równoznaczna $\mathrm{z}$ afirmacją tezy o dopuszczalności aborcji. Nie da się jednak ukryć, że w tym toku rozumowania czyha pewne niebezpieczeństwo. Otóż bez względu na brak aprobaty przez osobę B zabójstwa osoby A wykorzystanie do prze-

${ }_{19}$ Jak się bada bezpieczeństwo szczepionek?, https://szczepienia.pzh.gov.pl/wszystko-o-szczepieniach/jak-sie-bada-bezpieczenstwo-szczepionek/?strona=6\#czy-w-produkcjiszczepionek-dostepnych-w-polsce-wykorzystywany-jest-material-pochodzacy-od-czlowieka (dostęp: 09.02.2021). 
szczepu organu pozyskanego w wyniku morderstwa mogłoby dla osób niegodziwych stanowić zachętę do upowszechnienia takiego procederu. Innymi słowy - mówiąc językiem rynku - popyt rodzi podaż. Pojawia się w związku z tym uzasadniona obawa, że bierna i otwarta postawa biorcy staje się milczącą aprobatą podobnych praktyk w przyszłości (w rzeczywistości mamy już przecież do czynienia $\mathrm{z}$ handlem ludzkimi organami uzyskanymi w sposób niegodziwy). Podobnie, aprobata technologii opartych na ludzkich liniach komórkowych mogłaby stać się milczącą zachętą do dalszych aborcji służących tym technologiom. Co więcej, postawmy się w sytuacji osoby B: z pewnością osoba B nie popiera zabójstwa osoby A, jednak trudno też zaprzeczyć, że w jakimś sensie osoba B przeżywa wewnętrzne zadowolenie $\mathrm{z}$ tego, że znalazł się dawca organu. Może się nawet zdarzyć tak, że radość z życia u osoby B będzie intensywniejsza niż rozgoryczenie śmiercią osoby $A$. Podobnie granica między podziwem użyteczności już istniejących ludzkich linii zarodkowych a dezaprobatą aborcji może się szybko zatrzeć i doprowadzić do paradoksalnej sytuacji, w której przeciwnik aborcji milcząco zgodzi się na wykonywanie kolejnych aborcji „cudzymi rękami”, w imię nauki, samemu nie biorąc moralnej odpowiedzialności za nie (prawdopodobnie zawsze znajdzie się ktoś, kto aborcję wykona bez zawahania).

Wydaje się, że tego typu obawy stoją u podstaw nauczania Kościoła katolickiego. W dokumencie Kongregacji Nauki Wiary Dignitas Personae czytamy:

[...] niewystarczające jest formułowane przez niektóre komitety etyczne kryterium niezależności, czyli uznanie, iż jest rzekomo etycznie godziwe wykorzystanie «materiału biologicznego» z niegodziwego źródła, pod warunkiem, że istnieje wyraźny rozdział pomiędzy tymi, którzy produkują, zamrażają i uśmiercają embriony, a uczonymi, którzy prowadzą doświadczenia naukowe. Kryterium niezależności nie wystarcza, by uniknąć sprzeczności w postawie osoby, która twierdzi, że nie popiera nieprawości popełnianej przez innych, ale jednocześnie akceptuje dla potrzeb własnej pracy „materiał biologiczny” uzyskiwany przez innych w wyniku takiej nieprawości. [...] Przyczyniłoby się to bowiem do wzrostu obojętności, jeśli nie wręcz poparcia dla takich działań, z jakimi spotykają się one w niektórych środowiskach medycznych i politycznych ${ }^{20}$.

${ }^{20}$ Kongregacja Nauki Wiary, Dignitas Personae, 34. 
W tym samym punkcie kongregacja pisze, że obowiązek odmowy stosowania przez badaczy materiału biologicznego niegodziwego pochodzenia wynika z obowiązku zarówno wyrażenia sprzeciwu, w zakresie dotyczącym własnej pracy badawczej, wobec niesprawiedliwych rozwiązań ustawodawczych, jak i potwierdzenia w sposób wyraźny wartości ludzkiego życia. W następnym akapicie kongregacja łagodzi nieco swoje stanowisko, stwierdzając, że istnieją ważne racje mogące częściowo usprawiedliwić wykorzystanie materiału biologicznego, o którym mowa (np. zagrożenie życia dziecka upoważnia rodziców do zastosowania szczepionki wyprodukowanej przy użyciu linii komórkowych niegodziwego pochodzenia), pod warunkiem wyrażenia głośnej dezaprobaty takiej praktyki. Ta sama idea prześwieca wypowiedziom Kościoła, odnoszącym się konkretnie do produkcji szczepionek przeciw COVID-19. W nocie Kongregacji Nauki Wiary z 21 grudnia 2020 roku czytamy, że godziwe moralnie używanie tego typu szczepionek („godziwe” ze względu na szczególne warunki czyniące je godziwym) nie stanowi samo z siebie legitymizacji dla praktyki aborcji i musi zakładać sprzeciw wobec tej praktyki ${ }^{21}$. Stanowisko to jest inspirowane nauczaniem Papieskiej Akademii Życia ${ }^{22}$. Wypowiedzi Kościoła w tej kwestii mają charakter przede wszystkim prewencyjny. W ich zamyśle tkwi wola powstrzymania kolejnych aborcji. Świat stanął już w obliczu praktyk aborcyjnych inspirowanych biomedycznie. Nicanor Austriaco podaje, że chińscy naukowcy niedawno stworzyli nową linię ludzkich komórek płodowych, pozyskanych z aborcji wyraźnie zaplanowanej do badań. Zdaniem Austriaco, było to działanie zupełnie nieuzasadnione - przede wszystkim dlatego, że zabito kolejny płód, ale również dlatego, że linię HEK-293 cechuje nadzwyczajna wydajność i niezawodność i w rzeczywistości nie zachodzi pilna potrzeba tworzenia nowych linii ${ }^{23}$.

${ }^{21}$ Zob. Kongregacja Nauki Wiary, Nota na temat moralnej oceny stosowania niektórych szczepionek przeciw COVID-19, 3.

${ }^{22}$ Zob. Papieska Akademia Życia, Rozważania moralne o szczepionkach przygotowanych na bazie komórek pochodzacych $z$ abortowanych płodów ludzkich, https:// www.corvelva.it/pl/approfondimenti/notizie/riflessioni-morali-circa-i-vaccini-preparatia-partire-da-cellule-provenienti-da-feti-umani-abortiti.html (dostęp: 10.02.2021).

${ }^{23}$ N.P.G. Austriaco, Moral Guidance on Using COVID-19 Vaccines Developed with Human Fetal Cell Lines, https://www.thepublicdiscourse.com/2020/05/63752/ (dostęp: 06.02.2021). 


\subsection{PRZYWŁASZCZENIE ZŁA}

„Przywłaszczenie zła” jest to termin, którego używa Austriaco $\mathrm{w}$ celu rozwiązania problemu godziwości wykorzystywania w biotechnologii ludzkich linii zarodkowych. Przywłaszczyciel zła to osoba, która czerpie korzyści ze zła popełnionego w przeszłości. Możemy powiedzieć, że człowiek, który świadomie kupuje skradziony przedmiot, przywłaszcza go sobie, czerpiąc korzyści z popełnionej kradzieży, a przez to w jakimś sensie legitymizuje dokonaną kradzież. Choć nabywca sam nie dokonał kradzieży, to wspiera on czyn niesprawiedliwy, a przez to sam staje się niesprawiedliwy. Razem z przedmiotem nabywca "przywłaszcza” zło kradzieży, nawet jeżeli sam by nigdy niczego nie ukradł. Gdyby to przywłaszczenie przyczyniło się w przyszłości do powstania kolejnego zła, to nabywca stałby się odpowiedzialny także za zło przyszłe. Mogłoby się to dokonać na dwa sposoby. Po pierwsze, złodziej, inspirując się postawą nabywcy, mógłby dojść do przekonania, że kradnąc nie uczynił niczego złego, zatem wolno mu dokonać kolejnych przestępstw. Taką sytuację Austriaco nazywa skandalem. Po drugie, złodziej mógłby zachować świadomość, że kradzież jest złem, ale otwarta postawa nabywcy mogłaby utwierdzić w złodzieju przekonanie, że w przyszłości nabywca znów kupi od niego skradziony towar - warto więc ukraść ponownie. To moralne wykroczenie Austriaco nazywa współpracą. Autor konkluduje, że gdyby któryś z tych dwóch scenariuszy został zrealizowany - skandal lub współpraca - to przywłaszczenie sobie skutków zła, dokonanego w przeszłości, jest niegodziwe. $W$ przeciwnym razie, przywłaszczenie byłoby godziwe, ale tylko ze względu na poważny i proporcjonalny powód, ponieważ - jak twierdzi autor - osoba cnotliwa powinna unikać jakiegokolwiek związku ze złem, nawet związku luźnego ${ }^{24}$.

Wydaje się, że rozumowanie Austriaco nie jest całkiem poprawne, gdyż nie uwzględnia jednego ważnego czynnika, który właściwie decyduje o tym, czy mamy do czynienia z przywłaszczeniem (dokonanego) zła. Trzeba przede wszystkim odpowiedzieć na pytanie, czy uczynione

${ }^{24}$ N.P.G. Austriaco, Moral Guidance on Using COVID-19 Vaccines Developed with Human Fetal Cell Lines, https://www.thepublicdiscourse.com/2020/05/63752/ (dostęp: 06.02.2021). 
zło jest w momencie nabycia skradzionego przedmiotu usuwalne. Jeżeli jest ono usuwalne, tzn. skradziony przedmiot można zwrócić, to każda świadoma współpraca nabywcy ze złodziejem jest niegodziwa (nabywca, mając świadomość posiadania skradzionego przedmiotu, powinien go oddać prawowitemu właścicielowi). Przywłaszczenie zła występuje zatem tylko wtedy, gdy zło trwa, jest „zawieszone” nad sprawcami, ponieważ wciąż istnieje możliwość oddania sprawiedliwości ofierze. Z przywłaszczeniem zła nie mamy natomiast do czynienia, kiedy zło się dokonało i nie można cofnąć jego skutków. Kiedy nie ma możliwości naprawienia zła (skradzionego przedmiotu z jakiegoś powodu nie da się już oddać właścicielowi ani jego spadkobiercom, tzn. przedmiot stracił właściciela), za zło kradzieży odpowiedzialny jest złodziej, ale nie nabywca. Natomiast nabywca faktycznie powinien rozważyć, czy zdobycie skradzionego przedmiotu nie stanie się powodem skandalu lub zachęty do dalszych kradzieży. Gdyby się takim powodem stało, to nabywca byłoby współodpowiedzialny za zło kolejne ${ }^{25}$.

Zauważmy, że w przywołanym wcześniej eksperymencie myślowym osoba A straciła życie i nic jej tego życia nie jest w stanie zwrócić (mówiąc dosadnie, serce straciło na zawsze swego właściciela). $Z$ tego tylko powodu osoba B może skorzystać z organu osoby A, nie wyrządzając krzywdy osobie A. Nie jest to więc przywłaszczenie zła morderstwa (zło już się zrealizowało, nie jest czymś aktualnym i nie szkodzi więcej poszkodowanemu). To uwaga bardzo istotna w kontekście problemu linii zarodkowych. Uśmierconym przed laty płodom również nic nie jest w stanie przywrócić życia (zło się zrealizowało), a więc osoby korzystające z linii komórek będących potomkami komórek płodowych nie przywłaszczają sobie zła tamtych aborcji. Natomiast w indywidualnych przypadkach trzeba by rozważyć - zgodnie z intuicją Austriaco - czy postępowanie ludzi korzystających z linii zarodkowych nie staje się przyczyną skandalu lub zachętą do nowego zła. W tym wypadku mielibyśmy do czynienia już z kauzalnością postępową, a nie retroaktywną. Prawdopodobnie $\mathrm{z}$ tego powodu stanowisko Kościoła katolickiego w sprawie szczepionek wyprodukowanych dzięki ludzkim liniom zarodkowym jest tak bardzo

${ }^{25}$ Oczywiście jest to rozumowanie bardzo uproszczone. W praktyce skradziony przedmiot podlega stosownym regulacjom prawnym i utrata właściciela, o której tu mowa, wiąże się zwykle ze spełnieniem określonych przepisów. 
zachowawcze i kładzie nacisk na korzystanie - w miarę możliwości - ze szczepionek, których proces produkcji nie będzie w przyszłości budził obaw związanych z naruszeniem godności jakiejkolwiek osoby ludzkiej.

\subsection{WSPÓŁUDZIAŁ W ABORCJI A SPRAWCZOŚĆ RETROAKTYWNA}

Na gruncie personalizmu chrześcijańskiego każde umyślne przerwanie ciąży jest uchybieniem godności osobowej (w wyjątkowych przypadkach, w których można by odnieść się do zasady podwójnego skutku, śmierć dziecka bywa dopuszczona, choć nie jest bezpośrednio zamierzona) i nie ma znaczenia to, że jedna aborcja może się przyczynić do uratowania życia lub zdrowia wielu ludzi. Odpowiedzialność moralną ponoszą w pierwszym rzędzie matka, która decyduje się na przerwanie ciąży, oraz pracownik medyczny, który wykonuje zabieg. Są to osoby, których działanie ma charakter bezpośredni. Współudział w tym działaniu może mieć jednak większa grupa osób. W etyce przyjmuje się zwykle dwa rodzaje współudziału:

- współudział formalny - polega on na asystowaniu przy wykonywaniu działania, połączonym z podzielaniem intencji sprawcy działania (np. osoby wspólnie planujące napad są współodpowiedzialne za ten napad lub właściciele klinik aborcyjnych są współodpowiedzialni za wykonane tam aborcje),

- współudział materialny - polega on na zewnętrznym współdziałaniu, jednak bez dzielenia intencji ze sprawcą działania (np. sprzedawca $\mathrm{w}$ aptece, który $\mathrm{z}$ polecania pracodawcy wydaje środki wczesnoporonne, choć sam ich stosowanie uważa za niegodziwe, albo żołnierz, który zostaje zmuszony rozkazem do wykonania wyroku śmierci).

Postawmy teraz pytanie, czy osoby wytwarzające szczepionki przeciw COVID-19, używając do tego linii HEK-293 i PER.C5, oraz osoby przyjmujące te szczepionki, jak również wszystkie osoby wykorzystujące w celach badawczych ludzkie linie zarodkowe, biorą udział w aborcjach w sposób formalny lub materialny. To oczywiste, że nie zachodzi żaden z tych rodzajów współudziału. Współudział materialny w aborcjach dokonanych przed laty nie jest możliwy, ponieważ żadne ludzkie działania 
materialne nie oddziałują wstecz (skutek nie może być wcześniejszy od przyczyny). Jakakolwiek współodpowiedzialność ludzi współczesnych za minione zdarzenia musiałaby zakładać moc działania retroaktywnego, a tego po prostu zabraniają prawa fizyki ${ }^{26}$. W wykonaniu aborcji przed laty brały udział bardzo konkretne osoby. Z tego samego powodu nie możemy mówić o współudziale formalnym w tych aborcjach. Nawet jeżeli ktoś jest promotorem aborcji, to żadna głoszona przez niego dzisiaj teza proaborcyjna nie jest w stanie przyczynować aborcji dokonanych w latach 1972 i 1985. Skoro tak, to - wbrew opiniom niektórych autorów - nie jest wewnętrznie sprzeczna postawa, zgodnie z którą nie podziela się „zła” aborcji, ani nie jest się w aborcję zaangażowanym, ale akceptuje się do badań materiał biologiczny otrzymany w wyniku moralnie nagannego postępowania ${ }^{27}$. Sprzeczna byłaby taka postawa, w której ktoś z jednej strony nie akceptuje „zła” aborcji, a z drugiej bierze w niej (współ)udział. Osoba konsekwentna, która nie akceptuje „zła” zaistniałych w przeszłości aborcji, nie będzie akceptowała ewentualnych aborcji kolejnych. Nawet czyjeś dzisiejsze stwierdzenie, że tamte aborcje powinny były się dokonać, nie czyni jeszcze człowieka, który tak twierdzi, odpowiedzialnym za nie, choć oczywiście może stać się elementem promocji takich zabiegów w przyszłości.

\subsection{ZAWARTOŚĆ SZCZEPIONEK PRZECIW COVID-19}

W przypadku współczesnych linii komórkowych nie mamy już do czynienia $\mathrm{z}$ materiałem pozyskanym $\mathrm{z}$ aborcji, lecz $\mathrm{z}$ materiałem wyhodowanym in vitro. Papieska Akademia Życia w nocie z dnia 31 lipca 2017 r. podkreśla, że obecnie istniejące linie komórkowe są bardzo odległe od pierwotnych aborcji, w związku z tym ich stosowanie nie implikuje już moralnej współpracy ze złem dokonanym w przeszłości. Zło $\mathrm{w}$ sensie moralnym kryje się $\mathrm{w}$ działaniu, a nie w rzeczach lub materii jako takiej ${ }^{28}$. Podtrzymywanie przy życiu linii komórkowych nie wiąże się

${ }^{26}$ Zobrazowaniu tego, że nie da się wysłać żadnego sygnału w przeszłość, służy stożek Minkowskiego.

27 Zob. T. Orłowski, Szczepionki produkowane na liniach komórkowych pochodzenia płodowego - problemy etyczne, „Studia Redemptorystowskie” 9-1 (2011), s. 85.

${ }_{28}$ Pontificia Accademia per la Vita, Nota circa l'uso dei vaccini, http://www.acad- 
z koniecznością dokonywania kolejnych działań niemoralnych. Rektor Katolickiego Uniwersytetu Ameryki w Waszyngtonie John Garvey podkreśla, że linia HEK-293 jest tak powszechnie stosowana, że osobie zajmującej się biomedycyną praktycznie bardzo trudno uniknąć kontaktu $\mathrm{z}$ tą linią: „Ludzie musieliby porzucić na zawsze karierę w medycynie i naukach przyrodniczych, gdyby chcieli całkowicie uniknąć owej skazy”29.

Obecnie wykorzystywane linie komórkowe nie zawierają komórek pochodzących z ludzkich płodów, ale dalekie ich „potomstwo”. Pod względem bytowym komórka, czy nawet tkanka ludzka, nie jest człowiekiem jest po prostu komórką ludzką. Trudno więc twierdzić, że do produkcji szczepionek wykorzystuje się ludzi (płody). Stosowanie tej technologii nie jest zatem wykroczeniem przeciwko jakiejkolwiek osoby (płodu) ze względu na nią samą (choć takim wykroczeniem według normy personalistycznej była oczywiście aborcja). W związku z tym, korzystanie ze szczepionek przeciw COVID-19, wyprodukowanych dzięki ludzkim liniom zarodkowym HEK-293 i PER.C5 (które de facto nie zawierają ani części, ani nawet komórek ludzkich płodów), nie powinno budzić obiekcji moralnych.

\section{ZAKOŃCZENIE}

Współczesne wykorzystywanie istniejących ludzkich linii zarodkowych i szczepionek na nich opartych nie jest ani współudziałem materialnym, ani formalnym $\mathrm{w}$ aborcji, ponieważ nasze działania nie mają mocy retroaktywnej. Nie jest to również przywłaszczenie zła, ponieważ nie powoduje to trwania krzywdy osób poszkodowanych. Choć w duchu personalistycznym wspomniane aborcje nigdy nie mogą być usprawiedliwione, to nie dokonano ich w celach biomedycznych, a obecnie istniejące linie komórkowe materialnie nie mają już nic wspólnego z komórkami płodowymi. Wykorzystywanie linii zarodkowych w biotechnologii może jednak tworzyć złudzenie akceptacji aborcji jako środka do pozyskiwania

emyforlife.va/content/pav/it/the-academy/activity-academy/note-vaccini.html (dostęp: 15.02.2021).

29 J. Garvey, Commentary: What the HEK?, https://www.catholicnews.com/ commentary-what-the-hek/ (dostęp: 10.02.2021). 
takich linii, stąd wydaje się, że postawa personalistyczna domaga się w takiej sytuacji jednoznacznej retoryki promującej życie i godność osobową. Niniejsza praca nie wyczerpuje zasobu zagadnień związanych z technologiami korzystającymi z linii komórkowych. Na osobne opracowanie zasługuje choćby problem godziwości czerpania zysków ze sprzedaży ludzkiego materiału biologicznego. Sześć lat po wyprowadzeniu swojego słynnego szczepu WI-38, Hayflick zebrał zapasy komórek i od zainteresowanych badaczy zaczął pobierać opłaty za ich wysyłkę. To wywołało wojnę prawną $\mathrm{z}$ amerykańskim National Institutes of Health w Bethesda. Próbowano rozstrzygnąć, kto jest tak naprawdę właścicielem komórek. Walka niemal zniszczyła karierę Hayflicka i zrodziła pytania o to, czy (lub jak) naukowcy powinni czerpać zyski z tego typu wynalazków ${ }^{30}$. Jak widać, intensywny rozwój techniki dostarcza dziś szeregu pytań, na które bioetyka musi dawać zawsze jednoznaczne odpowiedzi, aby człowiek zachował swój podmiotowy charakter, a nie stał się jedynie przedmiotem $\mathrm{w}$ walce o doskonalenie gatunku.

\section{BIBLIOGRAFIA}

Austriaco N.P.G., Moral Guidance on Using COVID-19 Vaccines Developed with Human Fetal Cell Lines, https://www.thepublicdiscourse.com/2020/05/63752/ (dostęp: 06.02.2021).

Bednarski F. W., „Osobie jako osobie należna jest od osoby jako osoby afirmacja”, „Roczniki Filozoficzne" 29/2 (1981), s. 112-117.

Borkowski L., Drąg M., Fal A.M. i in. Szczepienia przeciw COVID-19. Innowacyjne technologie i efektywność, Warszawa 2020.

Charakterystyka produktu leczniczego COVID-19 Vaccine AstraZeneca zawiesina do wstrzykiwań. Szczepionka przeciw COVID-19 (ChAdOx1-S [rekombinowana]), https://ec.europa.eu/health/documents/community-register/2021/20210129150842/anx_150842_pl.pdf (dostęp: 06.02.2021).

Dec I., Personalizm, w: Powszechna Encyklopedia Filozofii, t. 8, PTTA, Lublin 2007, s.122-127.

Dicks M.D.J., Spencer A. J., Edward N. i in. A novel chimpanzee adenovirus vector with low human seroprevalence: improved systems for vector derivation and comparative immunogenicity, „PLoS One”, 7 (2012), https://journals.plos.org/plosone/article?id=10.1371/journal.pone.0040385 (dostęp 06.02.2021).

${ }^{30}$ Zob. M. Wadman, Medical research: cell division, „Nature” 498 (2013), s. 423. 
Garvey J., Commentary: What the HEK?, https://www.catholicnews.com/commentary-what-the-hek/ (dostęp: 10.02.2021).

Jak się bada bezpieczeństwo szczepionek?, https://szczepienia.pzh.gov.pl/wszystko-o-szczepieniach/jak-sie-bada-bezpieczenstwo-szczepionek/?strona=6\#czy-w-produkcjiszczepionek-dostepnych-w-polsce-wykorzystywany-jest-material-pochodzacyod-czlowieka (dostęp: 09.02.2021).

Kongregacja Nauki Wiary, Dignitas Personae, http://www.vatican.va/roman_curia/congregations/cfaith/documents/rc_con_cfaith_doc_20081208_dignitas-personae_ pl.html (dostęp: 10.02.2021).

Leiva R., A Brief History of Human Diploid Cell Strains, „The National Catholic Bioethics Quarterly" 6 (2006), s. 443-452.

Lundstrom R., Plotkin S. i in. Gamma Globulin Prophylaxis; Inactivated Rubella Virus; Production and Biologics Control of Live Attenuated Rubella Virus Vaccines. Discussion on Session V, „American Journal of Diseases of Children 118 (1969), s. 372-381.

Maritain J., La personne et le bien commun, Paris 1947.

Orłowski T., Szczepionki produkowane na liniach komórkowych pochodzenia płodowego problemy etyczne, „Studia Redemptorystowskie” 9-1 (2011), s. 75-90.

Stasiak P., Sznitowska M., Zastosowanie hodowli komórkowych w badaniach biofarmaceutycznych, „Farmacja Polska” 66/3 (2010), s. 228-234.

Papieska Akademia Życia, Rozważania moralne o szczepionkach przygotowanych na bazie komórek pochodzacych z abortowanych płodów ludzkich, https://www.corvelva.it/ $\mathrm{pl} /$ approfondimenti/notizie/riflessioni-morali-circa-i-vaccini-preparati-a-partireda-cellule-provenienti-da-feti-umani-abortiti.html (dostęp: 10.02.2021).

Pontificia Accademia per la Vita, Nota circa l'uso dei vaccini, http://www.academyforlife.va/content/pav/it/the-academy/activity-academy/note-vaccini.html (dostęp: 15.02.2021).

Stanowisko Zespołu Ekspertów ds. Bioetycznych Konferencji Episkopatu Polski dotyczace szczepionek, https://episkopat.pl/zespol-ekspertow-ds-bioetycznych-kep-wsszczepionek-przeciwko-covid-19/ (dostęp: 10.02.2021).

Stokłosowa S. (red.), Hodowla komórek i tkanek, PWN, Warszawa 2006.

Styczeń T., Etyka czy etyki?, „Roczniki Filozoficzne” 29/2 (1981), s. 90-111.

Szczepionki nieetyczne i alternatywne, http://dobreszczepionki.pl/?page_id=2595 (dostęp: 03.02.2021).

Szostek A., Wokół afirmacji osoby. Próby uściśleń inspirowane dyskusja nad koncepcją etyki ks. Tadeusza Stycznia, „Roczniki Filozoficzne” 32/2 (1984), s. 149-166.

Wadman M., Medical research: cell division, „Nature” 498 (2013), s. 422-426.

Wojtyła K., Osoba i czyn, Kraków 1969.

Zespół Ekspertów ds. Bioetycznych Konferencji Episkopatu Polski, Stanowisko Zespołu Ekspertów ds. Bioetycznych Konferencji Episkopatu Polski dotyczace szczepionek, 17. 